Pamiętnik Literacki 2017, 3, s. 179-184
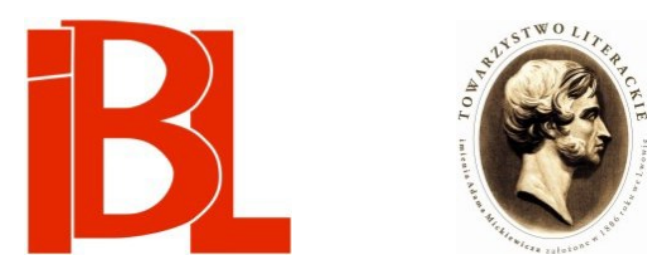

\title{
Włoski pierwowzór „Dworu cesarza tureckiego" Szymona Starowolskiego. \\ Rozwiązanie zagadki
}

Roman Krzywy 
Pamiętnik Literacki CVIII, 2017, z. 3, PL ISSN 0031-0514

DOI: $10.18318 / \mathrm{pl} .2017 .3 .11$

ROMAN KRZYWY Uniwersytet Warszawski

\section{WŁOSKI PIERWOWZÓR „DWORU CESARZA TURECKIEGO” SZYMONA STAROWOLSKIEGO ROZWIAZZANIE ZAGADKI}

Szymon Starowolski w przedmowie do Dworu cesarza tureckiego, utworu dedykowanego niespełna 20-letniemu Janowi Sobiepanowi Zamoyskiemu, rekomendował swe tłumaczenie głównie jako źródło wiedzy o rzeczywistości osmańskiej, z którą młody magnat nie miał okazji zetknąć się podczas podróży po Europie. Oznacza to, że publikacji przyświecały przede wszystkim cele poznawcze, aczkolwiek w literaturze przedmiotu zwraca się uwagę, iż dzieło mogło służyć także propagandzie, gdyż rok pierwodruku (1646) to czas intensywnych przygotowań Władysława IV Wazy do wojny z Turcją ${ }^{1}$. We wstępie Starowolski informuje ponadto, że Dwór zawiera wiadomości zebrane „od świadomych tego pogańskiego narodu ludzi” oraz „Z skryptu włoskiego, nowo teraz na świat w Rzymie wydanego"2. Pierwsza wskazówka sugeruje rozmaite amplifikacje wprowadzone do podstawy przekładu - nie znanego dotąd utworu, którego tytułu tudzież danych autora tłumacz poskapił czytelnikom. Druga identyfikuje miejsce druku (od razu należy zaznaczyć, że nie jest to informacja precyzyjna) i podpowiada, że polski pisarz korzystał ze wznowienia.

Nie wiedzieć czemu, Bohdan Baranowski nazwał pracę Starowolskiego „autoryzowanym przekładem”, dodając, iż stanowi ona tłumaczenie „nie jakiegoś poważnego dzieła wschodoznawczego, a typowej tandety, jakiej niemało drukowano w Italii” ${ }^{3}$. Z kolei Marian Bałczewski uznał utwór za przedsięwzięcie kompilacyjne ${ }^{4}$, dopatrując się sukcesu „tego swoistego czytadła”, podobnie jak Baranowski, w „pikantnych opisach haremowych przyjemności”, których rzekomo spragnieni byli

1 Zob. F. Bielak, Działalność naukowa Szymona Starowolskiego. „Studia i Materiały z Dziejów Nauki Polskiej" 1957, z. 1, s. 314.

2 Sz. St a row ols ki, Przedmowa. W: Dwór cesarza tureckiego i rezydencja jego $w$ Konstantynopolu. Wyd. 3. Kraków 1649, s. nlb. 5. Do edycji tej odsyłam dalej za pomocą skrótu S i numeru oznaczającego stronicę.

3 B. B a r a n o w s k i, Znajomość Wschodu w dawnej Polsce do XVIII wieku. Łódź 1950, s. 155. W jednym z nowszych opracowań (J. Szy m a ń s k a, Polscy wydawcy przekładów z literatur orientalnych $w X X$ wieku. Warszawa 2000) pojawiła się błędna informacja, iż Starowolski przetłumaczył utwór „Z włoskiego na łacinę”, uzupełniona równie mylącym przypisem, w którym podano, że Dwór cesarza tureckiego to przekład z łaciny (s. 14).

4 Badacz mógł zasugerować się treścią aprobacji cenzorskiej ks. Jakuba Uścieckiego z pierwszych wydań Dworu (1646, 1647, 1649). Duchowny określił tę książkę jako „przez w[ielebnego] ks[iędza] Simona Starowolskiego [...] zebraną z relacyj i z ksiag włoskich". Na adnotację zwrócił uwagę K. Estreicher (Bibliografia polska. T. 29. Kraków 1933, s. 190). 
XVII-wieczni czytelnicy nad Wisłą, oraz we wzroście zainteresowania Turcją w Rzeczypospolitej od schyłku rządów Władysława IV (zdaniem badacza, trwało ono do zawarcia pokoju karłowickiego w 1699 roku). Warto nadmienić, że Bałczewski określił informacje dotyczące etykiety związanej $z$ wyborem nałożnicy przez padyszacha jako bałamutne i przypisał ich pochodzenie przebywającym nad Bosforem obserwatorom weneckim, z których wiedzy miał korzystać Starowolski ${ }^{5}$.

Jerzy Nosowski, analizując zawartość przekładu, domniemywał, że Dwór cesarza tureckiego stanowi adaptacje „pamiętników Ricoldo de Monte Croce, misjonarza i podróżnika włoskiego w w. XIII”6. Tę hipotezę słusznie odrzuciła Anna Kupiszewska, według której zdawkowa wskazówka Starowolskiego na temat oryginału sugeruje raczej współczesne mu dzieło włoskie niż utwór $\mathrm{z}$ wieków średnich. Badaczka, dostrzegając zbieżność omówienia wyboru przez sułtana nałożnicy w pracy Starowolskiego i w relacji „niejakiego” Giovanniego Antonia, przypuszcza: „Być może jest to wskazówka, która pozwoli ustalić tytuł oraz autora włoskiego pierwowzoru"7. Formułując ten domysł, Kupiszewska odwołała się do książki popularyzatorskiej, w której podano, że pisarz ów przebywał na dworze Sulejmana Wspaniałego ${ }^{8}$ - co umożliwiło stwierdzenie, $z$ której dokładnie relacji pochodzi zbieżny fragment. Jest to mianowicie utwór I cinque libri della legge, religione et vita de' Turchi et della corte, et d'alcune guerre del Gran Turco Giovanniego Antonia Menavina z Genui (ok. 1492 - ok. poł. XVI w.). Dzieło wydano po raz pierwszy w roku 1548 jednocześnie w Wenecji i we Florencji (w tym drugim mieście jako Trattato dei costumi dei Turchi) ${ }^{9}$. Moją wątpliwość w przypadku tej hipotezy już na wstępie wzbudził fakt, iż Dwór przynosi sporo szczegółowych wiadomości o realiach z czasów Murada III (15741595). Zestawienie przekładu Starowolskiego $z$ deskrypcja genueńczyka kazało odrzucić przypuszczenie Kupiszewskiej i szukać innego wzoru.

5 M. Bałczewski, Gry i zabawy Turków osmańskich na podstawie polskich i obcych źródet od schytku średniowiecza do końca oświecenia. Warszawa 2000, s. 98, 162.

6 J. N o s o w s ki, Polska literatura polemiczno-antyislamistyczna XVI, XVII i XVIII $w$. Wybór tekstów $i$ komentarze. Z. 1. Warszawa 1974, s. 262, przypis 20. W nowszych opracowaniach częściej używa się wersji nazwiska: Riccoldo da Monte di Croce (Montecroce) bądź Riccoldo Pennini (ok. 1243 1320). Swe dzieło, znane jako Liber peregrinationis lub Itinerarium, podróżnik spisał po łacinie pod koniec XIII wieku. Oryginał był dostępny w czasach Starowolskiego jedynie w postaci rękopiśmiennych kopii; opublikowano go dopiero w XIX stuleciu. Przekład włoski ukazał się zaś w wieku XVIII (Itinerario ai paesi orientali. Firenze 1793), więc także o wiele za późno, by mógł mieć znaczenie dla niniejszych rozważań. Zob. P. A m at di San Fili p p o, Bibliografia dei viaggiatori italiani. Roma 1874, s. 16-17.

7 A. Ku p i s ze w s k a, Obraz Stambułu $w$ dziele „Dwór cesarza tureckiego i rezydencja jego $w$ Konstantynopolu" autorstwa Szymona Starowolskiego i jego wptyw na ksztattowanie postaw szlachty polskiej wobec Turcji i Turków. W zb.: Sarmatismus versus Orientalismus in Mitteleuropa / Sarmatyzm versus orientalizm w Europie Środkowej. Hrsg. M. Dłu go s z, P. O. S cholz. Berlin 2013, s. 217, przypis 10 .

8 Zob. W. Michalska-Krajewska, Tajemnice haremu. Kobieta $w$ świecie islamu. Warszawa 2003, s. 93.

9 Druk oparty jest na manuskrypcie z 1519 roku, zachowanym w rzymskiej Biblioteca Corsiniana, który został opatrzony łacińskim tytułem De rebus et moribus Turcarum (tekst główny po włosku). Zob. P. Schwarz Lausten, Giovanni Antonio Menavino. W zb.: Christian-Muslim Relations: A Bibliographical History. T. 6: Western Europe (1500-1600). Ed. D. Th o m a s, J. Ch e s w or th. Leiden-Boston 2014. 
Podczas kwerendy zwróciłem uwagę na relację autora o pokolenie młodszego od Giovanniego Antonia, lewantyńskiego Żyda znanego w Europie Zachodniej jako Domenico Hierosolimitano (1552/55-1622), którego wspomnienia, spisane w roku 1611, podał do druku Alfonso Chierici w publikacji Vera relatione della gran città di Costantinopoli et in particolare del serraglio del Gran Turco (Bracciano: per Andrea Fei, 1621, 1639).

Autor relacji był pierwotnie rabinem o imieniu Samuel. Przyszedł na świat w palestyńskim mieście Safed (część opracowań podaje, że w Jerozolimie), gdzie studiował Talmud i nauki medyczne. W drugiej połowie lat siedemdziesiatych wieku XVI zawędrował do Stambułu i został tam lekarzem nadwornym Murada III. Około roku 1580 towarzyszył siostrze sułtana, Gevheri Müluk, podczas pielgrzymki do Mekki, co tłumaczy nader precyzyjny opis nabożnych wędrówek w Vera relatione. Nie wiadomo, kiedy dokładnie opuścił stolicę Osmanów; ze źródeł zachowanych w archiwach włoskich wiemy tylko, że jako medyk pracował 12 lat. Znad Bosforu udał się do Wenecji, gdzie w 1593 roku przeszedł na katolicyzm, przyjmując na chrzcie imię Domenico. Jako konwertyta znalazł szybko zatrudnienie, choć nie w wyuczonym zawodzie. Najpierw pracował w Mantui jako cenzor ksiażek hebrajskich, następnie - około 1606 roku - na zaproszenie kardynała Fryderyka Boromeusza przybył do Mediolanu i trudnił się tłumaczeniem $z$ języka hebrajskiego w założonej przez purpurata Bibliotece Ambrozjańskiej. W roku 1609 bądź 1610 przeniósł się do Rzymu, gdzie pełnił funkcję cenzora w Kongregacji Nauki Wiary oraz wykładał język hebrajski w Collegio dei Neofiti ${ }^{10}$.

Brak natomiast danych na temat Alfonsa Chiericiego. Nie wiadomo, kim był (na karcie tytułowej widnieje tylko wskazówka, że pochodził z Bolonii) ani w jaki sposób wszedł w posiadanie manuskryptu zawierającego relację (karta tytułowa editio princeps informuje enigmatycznie: „cavata dal vero originale del Sig. Domenico Hierosolimitano"; we wznowieniu z 1639 roku adnotację opuszczono). Dedykacje w obu XVII-wiecznych wydaniach świadczą, że zabiegał nimi o względy możnych, przywłaszczając sobie cudza pracę ${ }^{11}$.

Starowolski - przypomnijmy - podał, że korzystał z tekstu Vera relatione „nowo teraz na świat w Rzymie wydanego", co sugeruje, iż najprawdopodobniej tłumaczył ze wznowienia. Obie edycje opublikowano w Bracciano, położonym kilkadziesiąt kilometrów na północ od Wiecznego Miasta. Tłumacz wskazał zatem miejsce publikacji jedynie w przybliżeniu, być może wychodząc z założenia, że nazwa siedziby rodu Orsinich niewiele powie większości jego rodaków. Przekład jest stosunkowo wierny, choć nie na tyle, by mówić o tłumaczeniu literalnym. Jak większość staropolskich translacji, Dwór cesarza tureckiego można uznać za adaptację dostosowująca oryginał do nowych potrzeb czytelniczych.

Poza wymianą elementów ramy wydawniczej (listu dedykacyjnego) zasługują

Zob. M. Austin, wstęp w: Domenico's Istanbul. Transl. ... Ed. G. Lew is. Warminster 2001, s. I-X. - G. Preb or, Domenico Yerushalmi: His Life, Writings and Work as a Censor. „Materia giudaica" 15/16 (2010-2011).

11 Zob. Austin, op. cit., s. XI-XV. Tu też więcej informacji o domniemanym obiegu rękopisów zawierających relację, a także o innych amatorach pracy Domenica, którzy publikowali ją pod swymi nazwiskami. 
na uwage rozmaite dodatki pióra Starowolskiego oraz polonizacyjne ekwiwalenty i precyzujące sformułowania, których zadaniem było ułatwienie lektury rodzimemu odbiorcy. Od tłumacza pochodzą np. pierwszy i ostatni akapit deskrypcji, pozbawione odpowiednika $\mathrm{w}$ oryginale. $\mathrm{W}$ zakończeniu polski ksiądz zawarł myśli pozwalające zaliczyć całe przedsięwzięcie do piśmiennictwa propagandowego, choć w sposób nieco sztuczny, gdyż w tekście właściwie brak zdecydowanych akcentów ekscytarzowych:

Z czego wszytkiego każdy łatwie może poznać dostatek, wielmożność i potęgę tego tyrana, którego sobie nielekko ważąc, Pana Boga samego prosić potrzeba, aby hardą pychę jego starszy, dał oswobodzenie narodom chrześcijańskim pod srogim jarzmem niewoli jego stękającym. A sławnemu narodowi naszemu, którzy go najbliżej mieszkamy, dał mądrość, męstwo i jednostajną wolą ze wszytkim chrześcijaństwem czynić z nim o chwałę Krzyża Świętego i otrzymać zwycięstwo jako najszczęśliwsze. [S 75]

W polskiej adaptacji chętniej dochodziło do głosu moralizatorstwo religijne, nie polityczne ${ }^{12}$. Warto jednak zauważyć, że przedstawiając za pierwowzorem zwyczaje muzułmańskie, Starowolski nierzadko stawiał chrześcijanom wyznawców islamu za wzór pobożności, co nie zdarzało się zbyt często polskim autorom XVI i XVII stulecia ${ }^{13}$. Opis zachowań w meczetach tłumacz opatrzył napomnieniem: „oby tak naszy katolicy czynili przed ołtarzem, na którym się straszna ofiara odprawuje i Bóg sam w Naświętszym Sakramencie jest obecnym” (S 58), a panującą w świątyniach tureckich nabożną ciszę skwitował obszerną refleksją:

nauka nam, chrześcijanom, którzy kościoły nasze już za karczmy prawie u siebie mamy i nie tylko rozmawiamy w nich, co chcemy, ale i zaloty czyniemy, i jednania odprawujemy, i schadzki różne, i sejmiki powiatowe, za czym też nam Pan Bóg nie błogosławi, że domu Jego świętego nie szanujemy. Nigdy przeto nic dobrego nie uradziemy, a jeśli co uradziemy, tedy do skutku swego nie przywiedziemy. [S 59]

Skierowane do rodaków przymówki, dotyczące braku gorliwości religijnej, pojawiają się na kartach Dworu cesarza tureckiego znacznie częściej. Nieodmiennie wywołują je spostrzeżenia Domenica na temat pobożności muzułmanów. Rzadziej natomiast Starowolski formułował uwagi krytyczne. Opis tureckich bractw religijnych skomentowany został następująco: „A to też i diabeł ma swoje męczenniki i zakonniki, jakoby podrzeźniając Kościołowi Bożemu, gdzie dla Chrystusa Pana wszytko opuszczają ludzie pobożni” (S 49). Gdy z kolei mowa o tureckim zwyczaju, wiązanym przez dawnych podróżników $z$ religią, a polegającym na zakupie specjalnie chwytanych wcześniej ptaków po to, by je wypuścić na wolność, Starowolski dodał nie bez intencji dezawuującej: „Oby tak naszych więźniów chcieli wolno wypuszczać, od Tatar wykupując, których tam z Rusi tysiącami zaprowadzają" (S 74).

Do dygresji naturalizujących pierwowzór należy zaliczyć różnego rodzaju amplifikacje faktograficzne, które łączą opis z ojczyzną tłumacza. Oryginalną wzmiankę o paradzie zorganizowanej przed wyprawą Murada III na wojnę $z$ Persją uzupełnił Starowolski komentarzem:

12 W cytowanej już aprobacji ks. Uściecki zwraca też uwagę na informacyjne walory publikacji oraz na jej użyteczność „dla [...] zganienia głupstwa pogańskiego”.

13 Zob. R. Krzywy, Obraz Turcji i jej mieszkańców w „Poselstwie wielkim” (1732) Franciszka Gościeckiego na tle staropolskiego dyskursu antytureckiego. W zb.: Wschód muzułmański w literaturze polskiej. Idee i obrazy. Red. G. Czerwińs ki, A. Kon o pa c ki. Białystok 2016, s. 24-25. 
co widział pobożnej pamięci ks. Trzebiński, biskup przemyski i podkanclerzy koronny, kiedy podkomorzym jeszcze lwowskim będąc, był posłem do Porty. A tę przejażdżkę swoję tak szumną Turek dlatego czynił, iż był natenczas u niego w Konstantynopolu poseł perski, a toż się z swoją potencyją przed nim popisował, aby go był ustraszył, rozkazawszy przystawowi swojemu powiedzieć przed posłem, iż to wojsko, które tam gromadne widział przy cesarzu, sa to tylko kury w kojcu, bo ustawnie przy nim w Konstantynopolu siedzą, ale kiedy obaczy jonaków, którym się każe ze wszytkiego państwa zjachać, tam dopiero obaczy potęgę cesarza konstantynopolskiego, który siła takich królestw ma pod sobą, jakie jest Królestwo Perskie. Jakoż przecie był ciężki Persowi wtenczas Turek i jedenaście mu był prowincyj odją $1^{14}$. [S 43]

Inne zmiany wyjaśniają rodzimej publiczności realia przedstawione w Vera relatione. W oryginale można znaleźć np. informację o dochodach $\mathrm{z}$ łaźni publicznych: „cioè cinque aspri al più, che sono cinque baiocchi alla romana” ${ }^{15}$, która Starowolski wyraził następująco: „płacąc od osoby po piąciu aspr (jest to moneta turecka srebrna, podobna dzięgom moskiewskim)” (S 2). Z kolei włoski opis jednego ze stołecznych placów: „È lunga la piazza per due volte piazza Navona di Roma, et una volta e mezza più larga” ${ }^{16}$, Polak sparafrazował: „Ten rynek jest tak wielki jako rynek krakowski, poznosiwszy ratusz i wszytkie budynki jego” (S 11).

Gdy Domenico ukazuje paradny statek sułtana, nazywa go z włoska „Bucentoro”, po czym dodaje: „come un galeotto” 17 , co dla czytelnika polskiego mogłoby być w dosłownym przekładzie niejasne. Dlatego Starowolski tłumaczy: „ma swoję barkę zrobioną na kształt okrętu, jako jest Bucentaurus u Wenetów, na którym książę z senatem w Boże Wstąpienie wyjeżdża na morze” (S 42). Tym razem wyjaśnienie ma więc charakter dopowiedzenia wynikającego $z$ wiedzy tłumacza. Analogiczne uzupełnienie wprowadził Starowolski oddając fragment informujący, skąd do Turcji sprowadzane jest bydło. W oryginale podano, że tylko z Węgier, tymczasem lepiej obeznany z zagadnieniem Polak stwierdza: „z Węgier, z Wołoch i z krajów słowiańskich” (S 14). Niekiedy też zamieszczał Starowolski informacje aktualizujące. Gdy np. mowa o przywożeniu cytrusów „Z Kanei” (dziś: Chania), znaczącego portu weneckiego na Krecie, zauważa: „To miasto teraz Turek opanował roku 1645” (S 29).

Innego rodzaju zmiany dotyczą dyspozycji materiału przedstawionego w Vera relatione. Oryginał liczy pięć obszernych ksiag, których zawartość została streszczona na początku dzieła (lakoniczne opisy powtórzono w nagłówkach). Mimo to odnosi się wrażenie, że część tematów połączył autor dość przypadkowo. Rozwlekłość rozdziałów i przygodne sąsiedztwo pewnych partii najwidoczniej nie zadowalały Starowolskiego, skoro wprowadził odmienne rozwiązania kompozycyjne. Tekst podzielił na 24 krótkie całostki i nadał im własne tytuły. Gdy przy tym w obrębie niektórych zagadnień pojawiały się w oryginale dygresje, polski pisarz wyodrębniał je w nowym rozdziale, zmieniając nieraz kolejność passusów. Oto np. rozdział 23 (O peregrynacyjej do grobu Mahometowego) w podstawie przekładu pomieszczony

Mowa o misji dyplomatycznej Aleksandra Trzebińskiego, który posłował do Turcji w roku 1634, czyli za rządów Murada IV (1623-1640). Być może więc tłumacz sądził, że relacja odnosi się do czasów panowania tego sułtana? 
był wcześniej, w omówieniu jednej z zasad islamu, podczas gdy opis następnej znajduje się na samym końcu dzieła. Starowolski wyodrębnił ten fragment, dzięki czemu struktura omówienia jest bardziej klarowna. Także ostatni rozdział adaptacji (O święceniu uroczystych świąt mahometańskich) został wyjęty z innego ustępu, przy czym tłumacz zmienił kolejność wybranych akapitów, by tworzyły logiczniejszy wywód.

Zasygnalizowane w niniejszej notatce zmiany domagają się, oczywiście, wyczerpującego studium o zakroju komparatystycznym, które powinno objąc ekwiwalentyzację leksyki oryginału w przekładzie Starowolskiego (zwłaszcza sposób przyswojenia terminów orientalnych wydaje się wart uwagi). Jak sądzę, badania filologiczne nad Dworem wzbogaca wiedzę o dawnych strategiach translatologicznych, umożliwią też przygotowanie wiarygodnej edycji krytycznej tego staropolskiego „bestselleru”, stanowiącego w Rzeczypospolitej XVII i początku XVIII wieku jedno z głównych źródeł wiedzy na temat wierzeń i obyczajów muzułmańskich ${ }^{18}$. Konsekwencją wskazania oryginału Dworu cesarza tureckiego powinno być przesunięcie utworu w bibliografii pism Starowolskiego z wykazu dzieł autorskich do działu zawierającego przekłady.

\author{
Abstract \\ ROMAN KRZYWY University of Warsaw
}

\title{
ITALIAN ORIGINAL OF SZYMON STAROWOLSKI'S “DWÓR CESARZA TURECKIEGO” (“THE COURT OF THE TURKISH EMPEROR”) THE PUZZLE'S SOLUTION
}

The author of the article identified the Italian original of Szymon Starowolski's Dwór cesarza tureckiego (The Court of the Turkish Emperor, 1646), a formerly vastly popular piece of prose which mingles a topographic description and practical particulars (referring to e.g. trade) with a presentation of customs at the sultan's court and with informations about Islam. The Polish writer translated the memories of a Levantine Jew known as Domenico Hierosolimitano (1552/55-1622) and published by Alfonso Chierici under the title Vera relatione della gran città di Costantinopoli et in particolare del serraglio del Gran Turco (Bracciano 1621, second ed. 1639). Most probably Starowolski used the second edition and adapted the original to compose his translation in various ways, namely made additions, specified the original wording, divided the original into smaller chapters, and changed the order of some text's fragments.

Pierwodruk: 1646, wznowienia: 1647, 1649, 1665, 1695, 1701, 1715. Dzieło publikowano jeszcze dwukrotnie w XIX wieku $(1844,1858)$. Adaptacja polska stała się z kolei podstawą tłumaczenia na język rosyjski (pierwodruk: Moskwa 1678, następnie kilka wydań). Zob. E s t r e i c h e r: loc. cit.; Bibliografia polska XIX stulecia. T. 4. Kraków 1878, s. 363. 